\title{
Characterization of tropical forage grass development pattern through the morphogenetic and structural characteristics ${ }^{1}$
}

\section{Carlindo Santos Rodrigues ${ }^{2}$, Domicio do Nascimento Júnior ${ }^{2}$, Sila Carneiro da Silva ${ }^{3}$, Márcia Cristina Teixeira da Silveira ${ }^{2}$, Braulio Maia de Lana Sousa ${ }^{2}$, Edenio Detmann ${ }^{2}$}

\author{
1 Financiado pelo CNPq. \\ 2 Departamento de Zootecnia - UFV, Viçosa, MG. \\ ${ }^{3}$ Departamento de Zootecnia - USP/ESALQ, Piracicaba, SP.
}

\begin{abstract}
An experiment was carried out with the objective to evaluate growth pattern of tropical forage grass under free growth by using morphogenetic and structural characteristics with the expectation of using this study for forage grass evaluation protocol. The experimental area was established with two cultivars of Panicum maximum Jacq. (Mombaca and Aruana), a hybrid cultivar of P. maximum Jacq. and P. Infestum BRA-7102 (Massai), two cultivars of Brachiaria brizantha (A. Rich.) Stapf (Marandu and Xaraes) and Molasses grass (Melinis minutiflora Beauv.) and jaragua grass (Hyparrhenia rufa (Nees) Stapf.). The grasses were planted in $1.0-\mathrm{m}^{2}$ experimental units with 24 plants arranged in a completely randomized block design with three replications. Growth pattern of the grasses was evaluated through mass development, tiller mortality, development stage and leaf longevity. Development patterns differed significantly among groups of grasses, indicating that the same available resources can be used in different manners by grasses from the same genus and/or species.
\end{abstract}

Key Words: ecophysiology, grass evaluation, morphogenesis, multivariate analysis

\section{Caracterização do padrão de desenvolvimento de gramíneas forrageiras tropicais por meio das características morfogênicas e estruturais}

\begin{abstract}
RESUMO - Um experimento foi conduzido com o objetivo de avaliar o padrão de desenvolvimento de gramíneas forrageiras tropicais em crescimento livre por meio das características morfogênicas e estruturais, com expectativa de uso desse estudo no protocolo de avaliação de gramíneas forrageiras. A área experimental foi estabelecida com dois cultivares de Panicum maximum Jacq. (Mombaça e Aruana), um cultivar híbrido de P. maximum Jacq. e P. infestum BRA-7102 (Massai), dois cultivares de Brachiaria brizantha (A. Rich.) Stapf (Marandu e Xaraés) e com os capins gordura (Melinis minutiflora Beauv.) e jaraguá (Hyparrhenia rufa (Nees) Stapf.). As gramíneas foram plantadas em unidades experimentais de 1,0 $\mathrm{m}^{2}$ com 24 plantas arranjadas em delineamento de blocos completos casualizados com três repetições. O padrão de desenvolvimento das gramíneas foi avaliado por meio do desenvolvimento de massa, da mortalidade de perfilhos, do estádio de desenvolvimento e da longevidade foliar. Os padrões de desenvolvimento diferiram significativamente entre os grupos de gramíneas, e isso indica que os mesmos recursos disponíveis podem ser usados de maneira diferente por gramíneas de mesmo gênero e/ou espécie.
\end{abstract}

Palavras-chave: análise multivariada, avaliação de gramíneas, ecofisiologia, morfogênese

\section{Introduction}

In the search for the understanding of morphophysiological processes and their interactions with the environment (Nascimento Júnior et al., 2002), important morphogenetic studies for the acquisition of this knowledge arise. Such importance is because those processes allow the understanding of the growth process, ecological adaptation and the dynamics of forage accumulation of a particular species, which contributes for the planning and adoption of efficient and suitable management practices for each type of forage plant.

Great changes and advances on the study of facts and processes that determine the use of tropical forage plants on pastures (Da Silva \& Nascimento Júnior, 2007) have been occurring. Many of these changes and advances arose from studies on morphogenesis, from which it has been searched to better understand the aspects related to shape and function of the plants. Information on this kind is still rare in comparison to the increasing number of options of tropical forage plants and also because of the 
difficulty on knowing each plant through pasture trials (Rodrigues et al., 2009). Thus, despite being laborious, the study of morphogenesis allows following up the dynamic of appearance of leaves and tillers, components of the target basic product, that is, forage biomass (Nascimento Júnior et al., 2004). This study allows better analyses of vegetal growth pattern, promoting basic knowledge needed for planning and defining further management strategies (Barbosa et al., 2007), because it enables identification of plants with different production potential inasmuch as some of the studied variables, as for example leaf and stem elongation rate, are highly correlated with forage accumulation rates.

Thus, the aim with this study was to evaluate the developmental pattern of tropical forage grasses growing free through morphogenetic and structural characteristics, with the expectation of using the information in the evaluation protocols and selection of forage grasses.

\section{Material and Methods}

The experiment was carried out at Universidade Federal de Viçosa (UFV), in Viçosa, Minas Gerais-Brazil (2045 ' $\mathrm{S}$ latitude, $42^{\circ} 51$ ' $\mathrm{W}$ longitude and $651 \mathrm{~m}$ of altitude), from November 2006 to May 2007. According to Köppen classification, the climate in the region is Cwa, subtropical, with dry season from May to October and rainy season from November to April (Figure 1).

The local soil is yellow red argisol with clay loam texture (EMBRAPA, 1999). According to the results from the chemical evaluation of the $0-20 \mathrm{~cm}$ layer, the average chemical

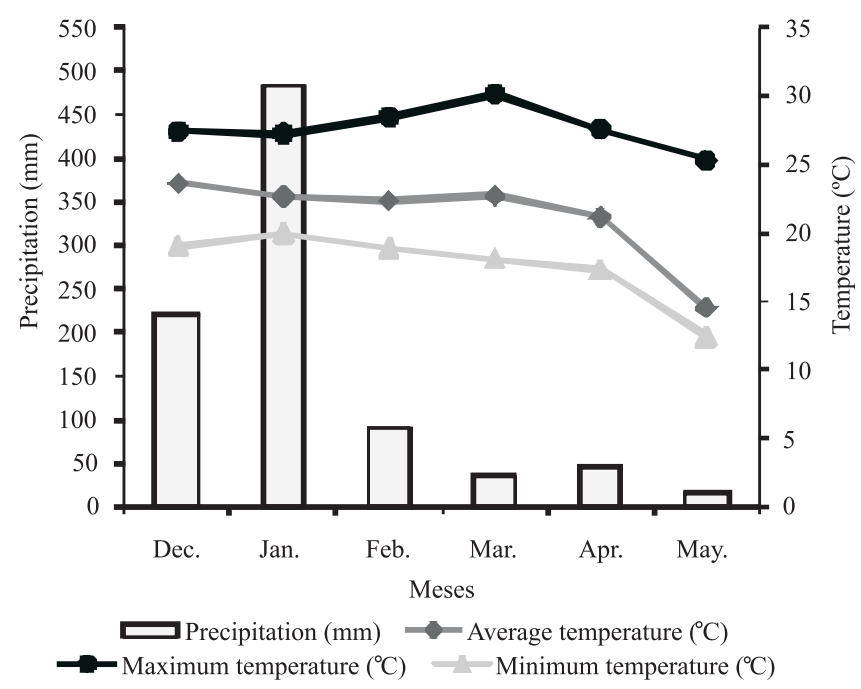

Figure 1 - Monthly means of maximal, mean and minimal temperatures and precipitation in the experimental period (December 2006 to May 2007). characteristics of the soil are the following: $\mathrm{pH}^{\text {in }} \mathrm{H}_{2} \mathrm{O}=5.5$; calcium $=2.1 \mathrm{cmol}_{\mathrm{c}} / \mathrm{dm}^{3} ;$ magnesium $=0.7 \mathrm{cmol}_{\mathrm{c}} / \mathrm{dm}^{3}$; phosphorus $=1.4 \mathrm{mg} / \mathrm{dm}^{3} ;$ potassium $=36 \mathrm{mg} / \mathrm{dm}^{3}$; aluminum $=0.0 \mathrm{cmol}_{\mathrm{c}} / \mathrm{dm}^{3} ; \mathrm{H}+\mathrm{Al}=4.3 \mathrm{cmol}_{\mathrm{c}} / \mathrm{dm}^{3}$; cation exchange capacity $=7.2 \mathrm{cmol}_{\mathrm{c}} / \mathrm{dm}^{3}$; effective cation exchange capacity $=2.9 \mathrm{cmol}_{C} / \mathrm{dm}^{3}$; base saturation $=40 \%$. Soil correction had been made in the experimental area in previous experiments; it was not detected the presence of exchangeable aluminum and $\mathrm{pH}$ values were within the range considered as satisfactory for establishment of grass under study (CFSEMG, 1999). Fertilization for formation of the plots was carried out using $100 \mathrm{~kg}$ of $\mathrm{P}_{2} \mathrm{O}_{5} \cdot \mathrm{ha}^{-1}$ in simple superphosphate applied in the planting line. Nitrogen and potassium fertilizations were carried out after the complete establishment of the plants, in quantities

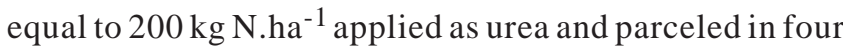
applications over the experimental period and $40 \mathrm{~kg}$ $\mathrm{K}_{2} \mathrm{O}$.ha ${ }^{-1}$ were applied in the form of potassium chloride in a single and broadcast application concomitant to the first nitrogen application.

The experimental area was established with two cultivars of Panicum maximum Jacq. (Mombaca and Aruana), a hybrid cultivar of $P$. maximum Jacq. and $P$. infestum BRA-7102 (Massai) two cultivars of Brachiaria brizantha (A. Rich.) Stapf (Marandu and Xaraes) and with Molasses grass (Melinis minutiflora Beauv.) and jaragua grass (Hyparrhenia rufa (Nees) Stapf.). Grasses were sown in plastic trays containing organic substrate and they were kept in greenhouses under irrigation until being transplanted to the field. The experimental area was plowed and harrowed and then cultivated with rotary hoe. After that, the plots $(1.00 \mathrm{~m} \times 1.00 \mathrm{~m})$ were prepared for transplanting of the seedlings on November $28^{\text {th }} 2006$.

Grasses were established in the experimental plots by using a complete random block design with three replications, totaling 21 experimental units. It was chosen to use random blocks because the experimental area is in a sloping terrain. Each experimental unit had four lines spaced by $0.20 \mathrm{~m}$ from each other, and, in each transplanting line, there were six plants spaced by $0.15 \mathrm{~m}$, totaling 24 plants per experimental unity.

The experiment started on December $12^{\text {th }}$ 2006, after establishment of the grasses in the experimental units. Because this experiment consisted of treatments which corresponded to cultivars and, or, to species of forage plants with contrasting morphology and growth habits, and therefore different defoliation management requirements, it was chosen to carry out the evaluations under free growth conditions to standardize the analyses. Thus, all forage plants were evaluated in the vegetative stage until $50 \%$ or 
more tillers presented visible inflorescences. To accomplish that task, visual analyses of the plots were made. Thus, the experimental period was extended to May $25^{\text {th }} 2007$, totaling 168 days of evaluations.

Morphogenetic and structural variables were evaluated by using tillers of two tussocks randomly marked in each plot, which were monitored twice weekly to check leaf appearance and elongation rates, stem elongation and leaf senescence. When inflorescence appeared on the monitored tiller, a new tiller was marked with the objective of evaluating growth and appearance of new leaves until the end of the experimental period. Therefore, it was chosen a tiller at vegetative stage and from the same tussock of the previous tiller. However, the tiller in reproductive stage continued to be monitored for evaluation of senescence rate of its leaves (Silveira et al., 2010). Under this circumstance, the number of monitored tillers increased.

The originally marked tillers, as well as the aerial tillers which emerged during the experimental period, were evaluated with the following characteristics: (a) length of the leaf blade and (b) classified as expanding, expanded, senescent or dead leaf. Leaves were rated as expanding leaf when their ligule was not exposed; they were rated as expanding leaves when the ligule was visible and/or their growth had ceased (this was considered after two consecutive evaluations with null variation in length of the leaf blade); they were senescent when part of the leaf blade showed signs of senescence (turning yellow and/or necrosis in any region on leaf blade); and rated as dead when more than $50 \%$ of the leaf blade was compromised by senescence.

Length of the leaves was measured according to leaf development. For expanded leaves, length was measured from the tip of the leave to its ligule. For expanding leaves, the same procedure was used considering the ligule of the last expanded leaf as a reference measurement. For senescence leaves, instead of the tip of the leaf, it was considered the point where the senescence process, turning yellow and/or necrosis on the green section of the leaf limbo, has advanced. For measurement of the stem elongation, it was considered the distance from the soil (or from the insertion point, in the case of aerial tillers) to the last completely expanded ligule.

Based on field data, rates of appearance (leaves.tiller ${ }^{-1}$. day $^{-1}$ ), elongation $\left(\mathrm{cm} \cdot\right.$ tiller $^{-1}$.day ${ }^{-1}$ ) and leaf senescence (cm.tiller ${ }^{-1}$.day ${ }^{-1}$ ), stem elongation $\left(\mathrm{cm} \cdot\right.$ tiller $^{-1}$.day ${ }^{-1}$ ), number of live leaves per tiller (cm.tiller ${ }^{1}$.day ${ }^{-1}$ ), leaf life span (days) and final length of the leaf blade $\left(\mathrm{cm}\right.$ tiller $\left.^{-1}\right)$ were calculated.
For evaluation of tillering, rates of appearance and death of tillers, two tussocks per plot were randomly labeled. In the first evaluation, all the tillers in each tussock were labeled with a colored plastic covered wire, counted and classified as basal or aerial. For every new evaluation, performed at every 30 days, all the existing labeled tillers were recounted; new tillers were labeled with a color different from the one used in previous labels, and the wires of dead tillers were collected for their accounting (Carvalho et al., 2000). Tillers considered as dead were those which disappeared or were dry or at advanced stage of senescence. Based on the counting, it was calculated appearance rates of aerial tiller (tiller.tiller ${ }^{-1} \cdot$ day $^{-1}$ ) and basal tillers (tiller.tiller ${ }^{-1}$.day ${ }^{-1}$ ), which resulted in total appearance rate of tillers (tiller.tiller ${ }^{-1}$.day ${ }^{-1}$ ), and mortality rate of aerial (tiller.tiller-1.day ${ }^{-1}$ ) and basal tillers (tiller.tiller ${ }^{-1}$.day ${ }^{-1}$ ), which resulted in total mortality rate of tillers (tiller.tiller ${ }^{-1}$.day ${ }^{-1}$ ).

For identification of the traits (factors) that described development of grasses, data were submitted to analysis of factors by using the statistical package SAS (Sas Institute, 2008). Factorial loads and retained fraction from total variation were adopted as factor selection criteria (commonality) (Johnson \& Wichern, 1998). This method has as its main objective to describe, if possible, covariance relationships among many variables, based on a small number of non-observable random quantities called factors (Johnson \& Wichern, 1998).

Variables were evaluated in two groups corresponding to the traits of aerial and basal tillers. The analyses were performed in a subset of data corresponding to summer season, including data taken from December $12^{\text {th }} 2006$ to March $20^{\text {th }} 2007$; and to autumn season, from March $21^{\text {st }}$ to May 25th 2007.

\section{Results and Discussion}

The evaluated variables were reduced to four, which explained $80 \%$ of total variation, outstanding commonality values above $50 \%$ in all evaluated variables (Table 1 ). The variables, leaf appearance and elongation rate, number of live leaves and basal and total tiller appearance rate positively influenced development of mass. Mortality of tillers was positively influenced by variables related to mortality of tiller (aerial, basal and total). However, development stage was positively influenced by leaf elongation rate and final length of leaf blade, which is characteristic of plant vegetative stage and it is also associated to plant reproductive stage inasmuch as, in all stages, plants have a particular length of leaves and before 
flowering, elongation leaf rate takes place, although leaves are smaller. In addition, development stage was negatively affected by stem elongation rate and with aerial tiller appearance rate, which are characteristic of reproductive stage. However, leaf longevity was negatively influenced by leaf lifespan and positively by leaf senescence rate.

Mass development individually explained $40 \%$ of total variation in the data set (Table 1). During summer, it presented negative factorial scores for mombaca, aruana and marandu grasses (Table 2), revealing a slower mass accumulation because those grasses priorize mass development through leaf elongation rate and number of live leaves, with low tillering and low rate of total tiller appearance.

Molasses, xaraes, jaragua and massai grasses presented positive factorial score for mass development during summer, which is a pattern contrasting to the other grasses. This fact can be associated with a greater investment on the

Table 1 - Factorial load and commonality of morphogenetic and tillering characteristics on grass development pattern

\begin{tabular}{|c|c|c|c|c|c|}
\hline \multirow[t]{2}{*}{ Variable } & \multicolumn{4}{|c|}{ Characterisitic } & \multirow[t]{2}{*}{ Commonality } \\
\hline & Mass development & Tiller mortality & Development stage & Leaf longevity & \\
\hline Leaf appearance & 0.7999 & -0.0949 & 0.0651 & 0.4314 & 0.8392 \\
\hline Leaf elongation & 0.7208 & -0.1244 & 0.5540 & 0.2047 & 0.8839 \\
\hline Number of live leaves & 0.7664 & -0.2277 & 0.4043 & -0.2512 & 0.8658 \\
\hline Leaf lifespan & -0.0533 & -0.2501 & 0.2460 & -0.7713 & 0.7208 \\
\hline Leaf senescence & 0.2919 & -0.0869 & 0.0568 & 0.8191 & 0.7669 \\
\hline Leaf blade final length & 0.1527 & -0.3350 & 0.8509 & 0.0582 & 0.8629 \\
\hline Stem elongation & -0.2662 & -0.4931 & -0.4315 & 0.0008 & 0.5002 \\
\hline Aerial tiller appearance & 0.0720 & 0.1295 & -0.6746 & 0.2669 & 0.5482 \\
\hline Basal tiller appearance & 0.9387 & -0.0931 & 0.0699 & 0.1690 & 0.9232 \\
\hline Tiller total appearance & 0.9037 & -0.1706 & -0.1868 & 0.1375 & 0.8996 \\
\hline Aerial tiller mortality & -0.0701 & 0.8837 & -0.2488 & -0.1084 & 0.8595 \\
\hline Basal tiller mortality & -0.3622 & 0.7504 & -0.2106 & 0.2225 & 0.7881 \\
\hline Tiller total mortality & -0.3285 & 0.8654 & -0.1799 & 0.1422 & 0.9094 \\
\hline Commonality & 3.8761 & 2.6493 & 2.0820 & 1.7605 & 10.3679 \\
\hline Explained variation & 0.4000 & 0.2100 & 0.1100 & 0.0800 & 0.8000 \\
\hline
\end{tabular}

Table 2 - Means of factorial scores of characteristics of forage grasses evaluated in summer and fall

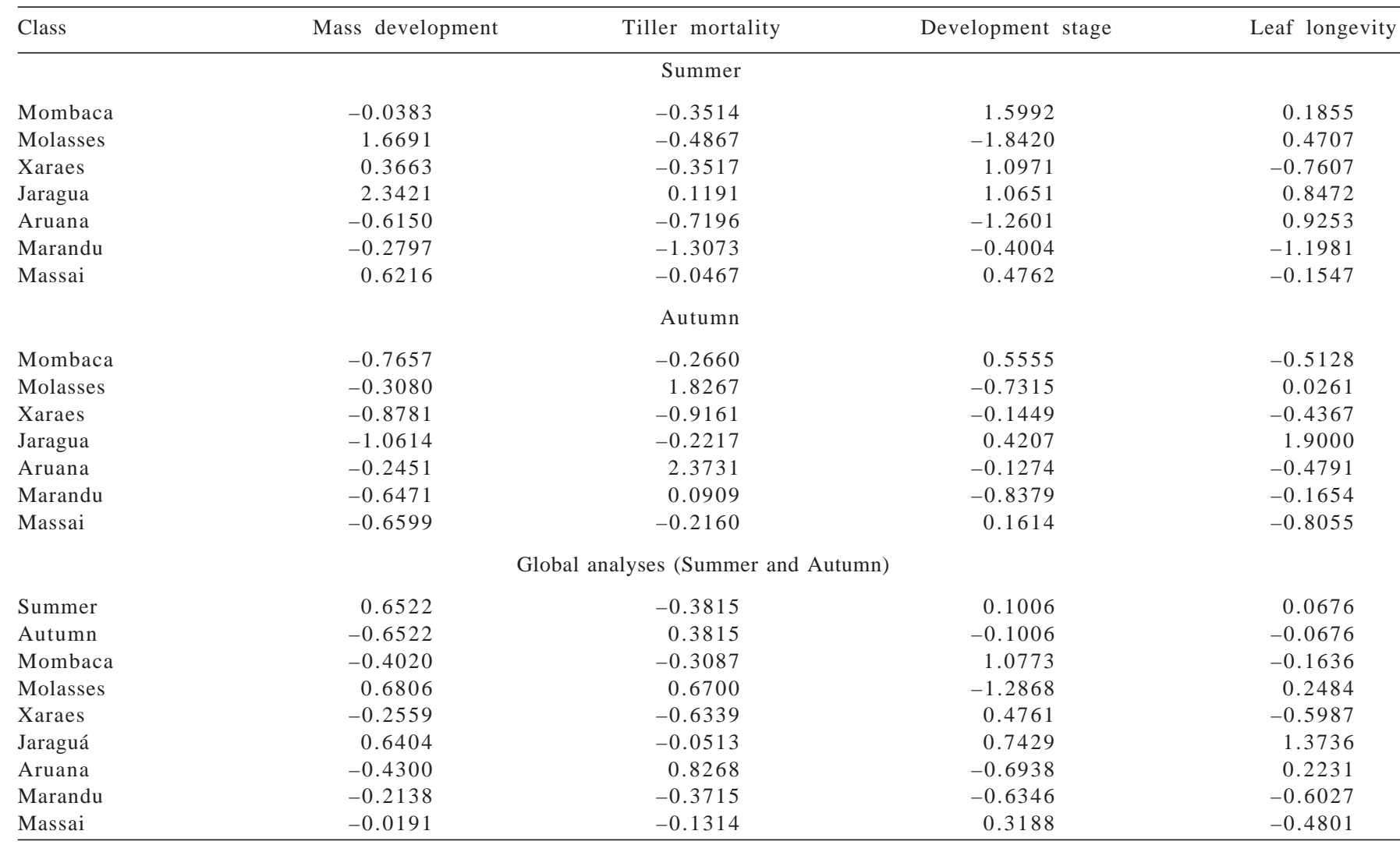


appearance of leaves and total and aerial tillers as means for defining factorial score for this group of grass.

Leaf appearance rate affects score determination for those grasses because it is responsible for potential number of points for appearance of new tillers (Davies, 1974). In addition to affecting pattern of mass development showed by jaragua grass, leaf elongation rate also contributes for the high score of this grass inasmuch as leaf elongation rate is positively correlated with biomass production (Horst et al., 1978). The pattern showed by the grasses reveals different ways of using morphogenetic and structural resources for mass development and increase of tissue flow (Rodrigues et al., 2009), regardless to genus or to species.

Morphogenetic characteristics are affected by environmental factors (Lemaire \& Chapman, 1996). When season changes from summer to autumn, there is a reduction in the photoperiod, temperature and precipitation (Figure 1). Therefore, all grasses showed negative pattern for mass development in the autumn (Table 2), reducing all characteristics that determined mass development, regardless of their relationship with development and size of individual tillers (leaf elongation and number of leaf per tiller - mass accumulation per investment on mass per tiller) or development and size of tiller population and leaf renewing (tillering and leaf appearance-mass accumulation by investment in population).

Leaf appearance rate responds immediately to any temperature variation perceived by the apical meristem (Peacock, 1975). Reduction in temperature reduces leaf appearance rate which reduces tillering, a fact recorded in this experiment. Leaf elongation rate was also reduced (Peacock, 1975; Lemaire \& Agnusdei, 2000), as a result of the lowest precipitation and water balance in this period.

Mombaca, xaraes and jaragua grasses were the grasses most affected in the fall and they showed the lowest mass development scores. Leaf elongation rate, number of live leaves and basal and total tiller appearance rate reduced drastically, especially in jaragua, which did not present tillering in the autumn, indicating the high seasonality of production. Patterns of mass development on marandu and massai were intermediate in comparison to the other grasses; however, they were very similar among each other, evidencing similarity in all integrating variables of mass development characteristic. According to Da Silva \& Sbrissia (2010), marandu pastures increase population densities of aerial tillers (axillaries) in autumn/winter season, as a way of compensating reduction in leaf elongation rate and increasing occupation of sites and their leaf area.
Taking into account the entire evaluation period, summer and autumn together (Table 2), mass development showed positive score in the summer and negative score in the autumn. Mass development was directly affected by weather conditions during all the evaluation period (Figure 1). Jaragua and molasses grass were the only ones that showed positive scores, a response of the consistent pattern of mass development characterized by higher leaf appearance rate in summer and autumn.

It can be inferred by this mass development, that grasses need a differentiate management, depending on the season of the year, because as it was seen before, positive scores for mass development occurred in the summer. Paciullo et al. (2005), when working with Cynodon dactylon in different seasons of the year, concluded that the highest accumulation of leaf biomass occurred in the summer and it was related mainly to the high leaf elongation rate in this season. This fact is caused by the higher tissue flow showed by the plants in seasons with better conditions of humidity, temperature and radiation, confirming that leaf growth, besides being controlled by availability of plant reserves and by genetic factors, also responds significantly to climate and management factors (Schnyder et al., 2000).

Usually, because of the association of these variables (appearance rate and leaf elongation, number of live leaves and appearance of total and basal tillers), it was possible to define contrasting grasses regarded to development of mass in each evaluation period, and also to identify grasses, from different genera, with similar mass development. This knowledge could support the planning and development of management strategies for more complex processes of grass evaluation, as a response of the plant to production and grazing in different seasons in the year.

Tiller mortality during the experimental period explained $21 \%$ of all variation in the data set (Table 1 ).

Factorial score of most grasses evaluated in the summer were negative except for jaragua grass, which presents positive factorial score (Table 2). Nevertheless, it can be concluded that all grasses showed low tiller mortality in this season because the score presented by this cultivar was low, close to zero. This might have happened because of the method of study (free growth) used, inasmuch as grazing, through apical bud removal, is the major cause of tiller mortality (Chapman \& Lemaire, 1993).

During the autumn, molasses, aruana and marandu grasses showed positive scores and Mombaca, xaraes, jaragua and massai grasses showed negative scores (Table 2), showing a different pattern among these two groups of plants regarded to tiller mortality in this season of the year. 
Tiller mortality pattern of molasses, aruana and marandu grasses was probably associated to presence and mortality of aerial tillers. Mortality of these tillers could have been accentuated by the early flowering of aruana and marandu grasses. Score of aruana grass was the highest, with higher values of tiller mortality rate. For molasses grass, flowering was the latest among all of them, showing inflorescence at the end of experimental period. Therefore, flowering did not contribute much for tiller mortality. Probably, this high mortality is associated with the higher populational density of tillers of this grass, especially because of the presence of aerial tillers, which have low longevity and are more susceptible to environmental changes. The high populational density of tillers may become an important cause of tiller deaths on pastures because it promotes a negative balance on carbon supply caused by light competition in the forage canopy (Lemaire \& Chapman, 1996).

Mombaca, xaraes, jaragua and massai grasses showed negative scores for tiller mortality in the autumn. Those grasses did not present aerial tillering in this season, so this fraction of the plant did not contribute for tiller mortality. Besides, those grasses showed late flowering and there was no mortality caused by flowering. Tiller mortality pattern in Mombaca, xaraes, jaragua and massai grasses indicate more longevity of tillers, contrasting to patterns of molasses, aruana and marandu grasses.

In general, tiller mortality score was negative in summer and positive in the autumn (Table 2), assuming that higher longevity of tillers in the summer and greater tiller mortality in the autumn could have happened because of the strong influence of flowering deaths of tillers.

Molasses and aruana grasses were the only ones that kept positive values in global evaluation, surely because of the significant production of low longevity aerial tillers. The other grasses showed opposite pattern of tiller mortality since they did not present aerial tiller or if they had showed it as for example marandu grass, the mortality effect of this plant component would not have been sufficient to keep positive score during global evaluation.

Identification of grasses with contrasting mortality pattern during the evaluated period occurred because of tiller mortality, as well as mass development. It could have been inferred that grasses respond differently to environmental changes regarded to tiller mortality, requiring defoliation strategies fitted to their physiological conditions in a specific season of the year, which allows increasing forage harvesting in detriment to losses caused by death of tillers.

Development stage of the grass directly affects quantity and quality of biomass produced and, when the plant is at its vegetative stage, the forage produced shows a better nutritional value in comparison to reproductive stage. In addition, during the transition process from one stage to the other, structural characteristics of the plant may change.

Interaction among leaf elongation rate, final length of leaf blade, stem elongation rate and appearance rate of aerial tillers constituted the development stage, which responded for $11 \%$ of data total variation (Table 1 ). Mombaca, xaraes, jaragua and massai grasses showed positive factorial scores during summer, contrasting to molasses, aruana and marandu grasses, whose scores were negative during this period (Table 2). The first group of grasses showed high values for stem elongation rate and final length of leaf blade, which is a characteristic of plants with longer vegetative period. For the second group of grasses, the values were high for stem elongation rate and appearance rate of aerial tillers, except for marandu grass, which did not show aerial tiller during this period and whose stem elongation rate was the cause of the negative score.

Rates of stem elongation and appearance of aerial tillers are variables that may be associated with the reproductive stage inasmuch as they stand out in the flowering period of grasses, a fact which was evidenced in aruana and marandu grasses, both with early flowering. However, molasses grass was the only one among the three grasses that showed negative scores and did not have early flowering. Nevertheless, it showed high rates of aerial tiller appearance and stem elongation because of the higher canopy density, causing great competition for light and $\mathrm{CO}_{2}$.

As the experimental period advanced, temperature and precipitation were reduced (Figure 1 ) in the autumn and this reduction affect grass development pattern during this season. Xaraes grass was the most affected and it showed positive factorial score in the summer and negative in the autumn (Table 2), as a consequence of the dramatic reduction in leaf elongation rate and final length of leaf blade and the increase in stem elongation rate because competition for light is intensified in the canopy and grass become closer to the reproductive stage, promoting stem elongation. The other grasses showed behavior similar to the one recorded in the summer, but with changes in absolute values of factorial scores because leaf elongation rate and final length of blade leaf of the grasses were reduced.

In the overall analyses, development stage showed positive factorial scores in the summer and negative factorial scores in the autumn (Table 2), that is, grasses priorize leaf elongation rate and final length of leaf blade, which represents vegetative stage. However, in the autumn, rates of stem elongation and aerial tiller appearance prevailed, which represents reproductive stage of the grasses. 
Nevertheless, this pattern was not so expressive because values in both periods were close to zero, implying in a similarity between development stages among periods, except for xaraes grass. Thus, the patterns showed by the grasses in the joint analysis of the development stage were similar to the one in the summer season which was analyzed singly, taking into account their own particularities.

The relationship between growth and leaf senescence processes defines leaf lifespan, which is the balance point between these two processes (Nabinger, 1997). Interaction among leaf lifespan and leaf senescence rate defined the trait leaf longevity, which responds for $8 \%$ of data total variation (Table 1 ).

During the summer, mombaca, molasses, jaragua and aruana grasses presented positive factorial scores (Table 2), contrasting with xaraes, marandu and massai grasses, which showed negative scores. This leaf longevity pattern indicates that in the grasses with positive factorial score, leaf senescence rate predominates over leaf life span whereas for those with negative factorial scores, the opposite happened, prioritizing leaf lifespan.

In the autumn, the contrast in leaf life span trait was evidenced in molasses and jaragua grasses, which showed positive score, indicating predominance of leaf senescence rate. Jaragua grass stood out because of its higher values of leaf senescence rate, which conferred high factorial score probably because tillering does not occur in this season. Thus, most of recorded values of leaf senescence rate were from leaves that grew in the summer considering that leaf appearance rate was reduced in the fall.

Mombaca, xaraes, aruana, marandu and massai grasses showed negative scores in the autumn, which means a higher lifespan. Higher leaf longevity usually may be associated to mechanisms of resource economy in climate adversity conditions, when there is a reduction in leaf elongation and in the tiller population density (Eckstein et al., 1999; Da Silva \& Sbrissia, 2010).

Factorial scores were positive in the summer and negative in the autumn (Table 2), suggesting a greater tissue flow for grasses in the summer because this period is characterized by medium to high temperatures, higher precipitation (Figure 1) and higher light radiation availability, the opposite to what happens in the fall. However, those values were little significant.

In the data joint analyses, it was clear the contrast between the group of grasses composed with molasses, jaragua and aruana grasses, whose scores were positive, and the group constituted of mombaca, xaraes, marandu and massai grasses, whose scores were negative.
Senescence leaf rate prevailed in the first group of grasses whereas in the second group, leaf lifespan was preponderant.

Leaf longevity is related to potential net accumulation of species biomass inasmuch as leaf lifespan and leaf senescence rate directly affect forage mass reproduction. Therefore, plants that present longer leaf longevity may be submitted to a greater interval between defoliations in comparison to the ones with shorter leaf longevity, which keep leaf area indices closer to a better efficiency of light interception and maximal average rates of forage accumulation (Nabinger \& Pontes, 2001).

Knowledge on morphogenetic characteristics of forage grasses is important and feasible to the evaluation process of forage plants inasmuch as ecological adaptation of plants to biotic and abiotic factors to which they are submitted can be understood. So, it can be recognized common functioning patterns (growth and development) of forage plants based on leaf elongation and appearance (production potential) on the duration of productive cycle (early, late or long) and on perpetuation strategy (tillering).

Accordingly, identification of common patterns of variation of structural and morphogenetic traits of plants can be done by using methods of multivariate analysis as analysis of factors, which was used in this study. This can be the basis for biological comprehension of manners and strategies of development and growth of the plants. This kind of knowledge can subside the planning of further experiments under pasture conditions, particularly at the final phase of the existing evaluation protocols.

Considering the present evaluation protocol of forage plants used by EMBRAPA (Valle et al., 2003), the study of morphogenetic characteristics could have already been

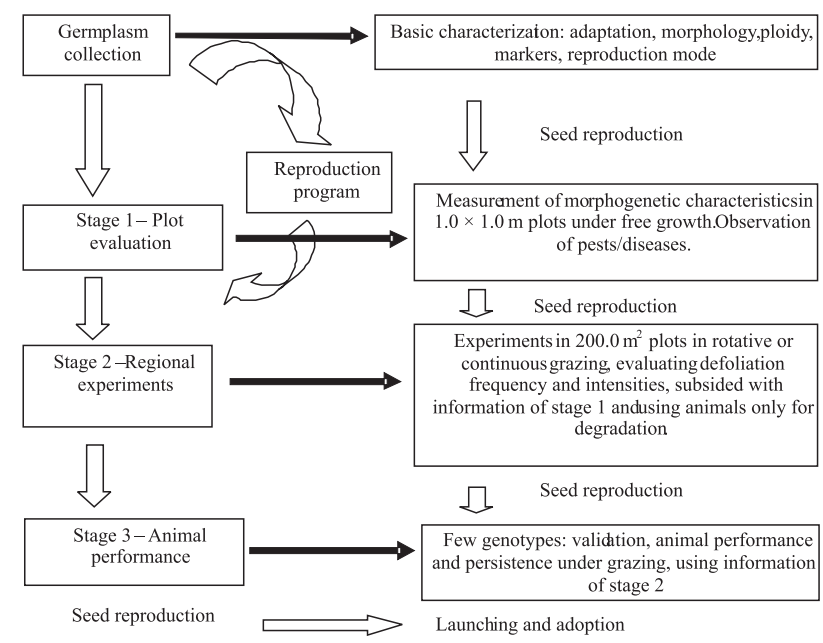

Figure 2 - Scheme of evaluation of forage plant germplasms for launching of a new variety (Valle et al., 2003) fitted by using morphogenetic traits. 
implemented in stage 1 , evaluating $1.0 \times 1.0 \mathrm{~m}$ plots together with evaluations on resistance and, or, on tolerance to pests and diseases (Figure 2). Therefore, important and objective information could have been used in stages 2 and 3, using a pasture management strategy more consistent to grass development pattern. Accordingly, it can be generated knowledge on functional responses of tropical forage plants which are useful for determining efficient management practices, ensuring satisfactory animal performance within the ecophysiological boundaries of forage plants.

\section{Conclusions}

The evaluated grasses use the available resources for growth and development in different manners. Evaluation of morphogenetic and structural traits can subside the planning of further protocols for evaluation and selection of new grass cultivars.

\section{Acknowledgement}

To CNPq and Departament of Animal Science of Federal University of Vicosa for the opportunity and the financial support as a master science scholarship for the first author. To the friends Mr. Nicolau, Wilton Ladeira, Anderson Moura Zanini, Karina Ellen Matias de Oliveira, Mirian Magalhães Xavier, Rosana Moura Oliveira, Hélida Monteiro and Karine Pena, for helping in the research project.

\section{References}

BARBOSA, R.A.; NASCIMENTO JÚNIOR, D.; EUCLIDES, V.P.B. et al. Capim-tanzânia submetido a combinações entre severidade e frequência de pastejo. Pesquisa Agropecuária Brasileira, v.42, n.3, p.329-340, 2007.

CARVALHO, C.A.B.; Da SILVA, S.C.; CARNEVALLI, R.A. et al. Perfilhamento e acúmulo de forragem em pastagens de Florakirk (Cynodon spp.) manejadas em quatro alturas de pasto. Boletim da Indústria Animal, v.57, n.1, p.39-51, 2000.

CHAPMAN, D.F.; LEMAIRE, G. Morphogenetic and structural determinants of plant regrowth after defoliation. In: BAKER, M.J. (Ed.). Grasslands for our eorld. Wellington: SIR Publishing, 1993. p.55-64.

COMISSÃO DE FERTILIDADE DO SOLO DO ESTADO DE MINAS GERAIS - CFSEMG. Recomendações para o uso de corretivos e fertilizantes em Minas Gerais: $5^{\text {a }}$ Aproximação. RIBEIRO, A.C. et al. (Ed.). Viçosa, MG: UFV, 1999. 359p.

DA SILVA, S.C.; NASCIMENTO JÚNIOR, D. Avanços na pesquisa com plantas forrageiras tropicais em pastagens: características morfofisiológicas e manejo do pastejo. Revista Brasileira de Zootecnia, v.36, p.122-138, 2007. (supl.).

DA SILVA, S.C; SBRISSIA, A.F. Análise de componentes principais entre características morfogênicas e estruturais em capimmarandu sob lotação contínua. Ciência Rural, v.40, n.3, p.690-693, 2010.
DAVIES, A. Leaf tissue remaining after cutting and regrowth in perennial ryegrass. Journal of Agricultural Science, v.82, p.165-172, 1974.

ECKSTEIN, R.L.; ECKSTEIN, R.L.; KARLSSON, P.S. et al. Leaf lifespan and nutrient resorption as determinants of plant nutrient conservation in temperatearctic regions. New Phytologist, v.143, p.177-189, 1999.

EMPRESA BRASILEIRA DE PESQUISA AGROPECUÁRIA EMBRAPA. Sistema brasileiro de classificação de solos. Brasília: EMBRAPA, 1999. 412p. (Produção de Informação).

HORST, G.L.; NELSON, C.J.; ASAY, K.H. Relationship of leaf elongation to forage yield of tall fescue genotypes. Crop Science, v.18, p.715-719, 1978.

JOHNSON, R.A.; WICHERN, D.W. Applied multivariate statistical analysis. 4.ed. New Jersey: Prentice-Hall, 1998. 816p.

LEMAIRE, G.; AGNUSDEI, M. Leaf tissue turn-over and efficiency of herbage utilization In: LEMAIRE, G.; HODGSON, J.; MORAES, A. et al. (Eds.). Grassland ecophysiology and grazing ecology. [S.1.]: CAB International, 2000. p.265-288.

LEMAIRE, G.; CHAPMAN, D.F. Tissue flows in grazed plant communities. In: HODGSON, J.; ILLIUS, A.W. (Eds.). The ecology and management of grazing systems. Oxon: CAB International, 1996. p.3-36

NABINGER, C. Eficiência do uso de pastagens: disponibilidade e perdas de forragem. In: SIMPÓSIO SOBRE MANEJO DA PASTAGEM. TEMA: FUNDAMENTOS DO PASTEJO ROTACIONADO, 14. 1997, Piracicaba. Anais... Piracicaba: FEALQ, 1997. p.231-251.

NABINGER, C.; PONTES, L.S. Morfogênese de plantas forrageiras e estrutura do pasto. In: REUNIÃO ANUAL DA SOCIDADE BRASILEIRA DE ZOOTECNIA, 38., 2001, Piracicaba. Anais.. Piracicaba: SBZ, 2001. p.755-771.

NASCIMENTO JÚNIOR, D.; Da SILVA, S.C.; ADESE, B. Perspectivas futuras do uso de gramíneas em pastejo. In: REUNIÃO ANUAL DA SOCIEDADE BRASILEIRA DE ZOOTECNIA, 31., 2004, Viçosa, MG. Anais... Campo Grande: Sociedade Brasileira de Zootecnia, 2004. p.130-141.

NASCIMENTO JÚNIOR, D.; NETO, A.F.G.; BARBOSA, R.A. et al. Fundamentos para o manejo de pastagens: Evolução e atualidades. In: SIMPÓSIO SOBRE MANEJO ESTRATÉGICO DA PASTAGEM, 1., 2002, Viçosa, MG. Anais... Viçosa, MG: Editora Suprema, 2002. p.149-196.

PACIULLO, D.S.C.; AROEIRA, L.J.M.; MORENZ, M.J.F. et al Morfogênese, características estruturais e acúmulo de forragem em pastagem de Cynodon dactylon, em diferentes estações do ano. Ciência Animal Brasileira, v.6, n.4, p.233-241, 2005.

PEACOCK, J.M. Temperature and leaf growth in Lolium perene. 1. The thermal microclimate: its measurement and relation to plant growth. Journal of Applied Ecology, v.12, p.115-123, 1975.

RODRIGUES, C.S; SILVEIRA, M.C.T.; NASCIMENTO JÚNIOR, D.; et al. Caracterização morfogênica e estrutural de quatro gramíneas forrageiras tropicais sob crescimento livre. In: REUNIÃO ANUAL DA SOCIEDADE BRASILEIRA DE ZOOTECNIA, 46., 2009, Maringá. Anais... Paraná: Sociedade Brasileira de Zootecnia. [2009]. (CD-ROM).

STATISTICAL ANALYSES SYSTEM - SAS. SAS/STAT: User's guide statistics. Version 9.0. Cary: 2008. (CD-ROM).

SCHNYDER, R.H.; SCHÄUFELE; R.; VISSER; R. et al. An integrated view of $\mathrm{c}$ and $\mathrm{n}$ uses in leaf growth zones of defoliated grasses. In: LEMAIRE, G.; HODGSON, J.; MORAES, A. et al. (Eds.). Grassland ecophysiology and grazing ecology. Wallingford: CAB International, 2000. p.41-60.

SILVEIRA, M.C.T.; NASCIMENTO JÚNIOR, D.; DA SILVA S.C. et al. Morphogenetic and structural comparative characterization of tropical forage grass cultivars under free growth. Scientia Agricola, v.19, n.2, p.136-142, 2010.

VALLE, C.B.; JANK, L.; RESENDE, R.M.S. et al. Lançamento de cultivares forrageiras: o processo e seus resultados - cvs. Massai, Pojuca, Campo Grande, Xaraés. In: SIMPÓSIO DE FORRAGICUlTURA E PASTAGENS, 4., 2003, Lavras. Anais.. Lavras, MG: UFLA, 2003. p.179-226. 